\title{
The Comparative Analysis of Accessibility Index Value of Government Internet Financial Reporting In Indonesia
}

\author{
Verawaty $^{1}$ \\ ${ }^{1}$ Department of Accounting, Bina Darma University, \\ Correspondence: Jl. Jenderal Ahmad Yani No. 3 Plaju Palembang 30164 Sumatera Selatan Indonesia
}

Received: November 27, 2015

Accepted: January 31, 2016

Available online: February 23, 2016

doi:10.11114/afa.v2i2.1214

URL: http://dx.doi.org/10.11114/afa.v2i2.1214

\begin{abstract}
The financial information through internet is called IFR (Internet Financial Reporting) which is a combination between the internet multimedia capability and capacity to communicate the financial information interactively. This study is aimed to compare the quality of financial reporting disclosures based on the accessibility of IFR on government website (e-government) by using Accessibility Index Value between two groups of samples. The study looks at Indonesia local government's use of the internet both in provincial and municipal government. The provincial government must be more highlighted by the public so it is hypothesized it will disclose information in its e-government with better format and quality than the municipal government measured by the index which shows the ability of some citizens to access the data provided in e-government. Based on the testing results with Mann Whitney Test, the results are not significant. The majority has not emphasized the importance of increasing accountability and widening the scope of measurement and reporting systems.
\end{abstract}

Keywords: e-government, Internet Financial Reporting, accessibility index value

\section{Introduction}

Government as an entity that invests in information technology in the form of e-government realizes the importance to satisfy the need for public information. It raises a question whether the public stakeholder of e-government has maximized the utilization of its use as well, so not only at the level that the local government must have e-government, but also optimize its utilization for the accounting aspect. The focus of this research is the public sector's financial disclosures through IFR (Internet Financial Reporting).

IFR is a fast-growing phenomenon. Many organizations publish their financial information on the internet. It is the reporting and disclosure of public sector accounting by using a government website media (e-government). IFR literature indicates the same purpose as the private sector that the public sector also uses the internet as a mechanism to disseminate reports and disclosures provided to the public stakeholders. It supports the statement of Wagenhofer (2003) that the IFR is related to the public sector accounting disclosure.

According to Oyelere et al (2003), IFR is a combination of capacity and capability of multimedia internet to communicate interactively about financial information. The financial statements are usually printed, but through the internet, the financial reports can be distributed more quickly as in the the term of timeliness aspect and are able to develop the usefulness of this technology to open up further to inform the financial statements as in the term of disclosure aspect. Financial information provided on the web includes the comprehensive sets of financial statements such as footnotes; partial sets of financial statements; and/or financial highlights which may include summary financial statements or extracts from such statements.

Actually, the financial statements reporting on the internet has not been regulated for the government in Indonesia. The global accessibility of financial reports on the internet can create possible implications for groups with interests in financial reporting, such as financial information preparers, users, auditors and regulators. Bagshaw (2000) argues that the global accessibility of financial reports and the absence of a global regulator necessitate the cooperation of national and international organization to ensure that financial information is the highest quality.

The enormous development of the internet and an increasing acceptance by its users has an accessibility issue. Major characteristics of the internet are that information can be accessed (almost) any time and everywhere, and generally at a 
low cost; the information is up-to-date; there are few limits on data availability; information can include dynamic presentations and multimedia; and there is the possibility of interactive information demand and supply. These developments have a significant effect on the dissemination of information and thus on the organizational structures of how these activities are performed. They also open up new and astounding opportunities for financial disclosure that affect all interested parties. These opportunities concern standard setters as well as regulators.

To be accessible, IFR must give the easiest way so the stakeholder can accept it properly. According to Style and Tennyson (2007), the accessibility concerns in how many steps are required to locate the financial report in the website. The need for control over IFR largely depends on the degree to which efficient solutions are currently being found in the community for financial information. Style and Tennyson (2007) discussed the association between the accessibility and the number of residents, resident income per capita, level of debt, and the financial position of the municipalities in USA.

With the easiest steps to access, it will describe the accountability itself. Recent public sector reforms have generally emphasized the importance of increasing accountability and widening the scope of measurement and reporting systems, as well as the use of information and communication technologies. Internet technologies provide public sector organizations with an opportunity to improve their accountability, to increase their responsiveness to the needs of citizens and to promote a change in the overall philosophy of government and organization of activities.

Based on the above statements, this study is aimed to compare the quality of financial reporting disclosures of provincial and municipal governments in Indonesia by using Accessibility Index Value developed by Styles and Tennyson (2000). The reasons for selecting the sample groups because the provincial government must be more highlighted by the public so it is hypothesized it will disclose information in its e-government with better format and quality in the term of accessibility matters than the municipal government.

Previous studies form the basis for formulating research hypotheses. There are some studies which discussed the availability of financial reports with internet media such as Groff and Pittman (2004) which examined the practice of 100 largest local governments in the USA, Laswad et al (2005) which examined the voluntary IFR at the local government in New Zealand, Styles and Tennyson (2007) examined the accessibility determinants of all local government financial reporting on the internet in USA. The studies of Indonesian are Verawaty (2010) which examined the availability of the IFR in the municipality government level in South Sumatera, Verawaty and Merina (2011) which examined the accessibility of the provincial government IFR in Indonesia by linking it with the implementation of Act No. 14 of 2008 on The Disclosure of Public Information, Verawaty (2012) which examined the availability of the IFR in the provincial government level in Indonesia, Verawaty (2014a) which examined the disclosure quality of local government in Indonesia by using a disclosure index developed by Cheng et al (2000), Verawaty (2014b) which examined the accessibility determinants of IFR of local government in Indonesia, Verawaty (2014c) which examined a missing link in national development accountability by assessing the accessibility of IFR of local government in Indonesia, and Jaya and Verawaty (2015) which examined the importance of increasing accountability and widening the scope of measurement and reporting systems, as well as the use of information and communication technologies to provide public need of government financial performances in Indonesia.

Jaya and Verawaty (2015) only revealed the accessibility on how many steps it takes to find the financial statements in e-government. But it did not compare the accessibility quality between provincial and municipal government. This research will discuss the quality of the IFR disclosure of the local government by using Mann Whitney Test with hypothesis that the provincial government will disclose information in its e-government with better format and quality than the municipal government.

The contribution of this study is to be a consideration for the local government in an effort to improve the implementation of e-government in the areas of accounting, which IFR is determined to fulfill its obligations as the provider of public information. Besides, for academics and researchers, this study is as a material input or additional reference if they want to develop an application-related research of IFR through e-government.

\section{Methodology}

The study population is all local governments in Indonesia, while the sample is divided into two. The first group is all provincial level governments in Indonesia. The reason is of that the provincial government is more highlighted by the public so that it is hypothesized that it disclose information in e-government with better format and quality than the municipal government in the term of accessibility matters.

The second group is determined by certain criteria or purposive sampling method. The specific criterion is that in each province will be chosen a municipal government as the broadest category of areas, the most populous, and the highest per capita income. It is based on Mussari and Steccolini (2006) that the sample which is not a government with large cities is considered not get high demands on their financial statements disclosure. In addition, the general criteria for each group of 
samples are to have e-government up to June 2015 and its status is not in under construction or maintenance status.

Data is collected through observation of the availability of e-government in the two groups of samples in order to be analyzed comparatively by assessing its accessibility based on Accessibility Index Value (Styles and Tennyson, 2007). To complete the analysis of the data, the researcher will use interviews with practitioners of local government authorities related to the IFR (Internet Financial Reporting) policy in the region. This is necessary because this study course will be exploratory because there has never been the same study conducted in Indonesia. The interview results will provide robustness aspect of the research results. In addition, other secondary sources are text books, scientific or popular articles, newspapers, and other sources from internet.

Here is the Calculation of Accessibility Index which is the basis for assessing how many steps it takes to find the financial statements in the e-government:

Table 1. Calculation of Accessibility Index Value

The accessibility index was calculated as follows for each government that provided CAFR* data on its official website:

1 point if official government website appears on first page of result for Google or Yahoo search using government name and state $(\mathrm{A})$.

+1 point if official government website has link to CAFR data on website homepage (B).

+1 Point if official government website has search engine that finds CAFR using terms CAFR and/or financial statements (C).

+1 Point if 3 or less web pages (or clicks of mouse) to view CAFR data from government website homepage (D). \pm

+1 Point if CAFR provided on official government website as indexed pdf file(s) or HTML format (E).

+1 Point if government provides CAFR data in more than one file; files for different sections/pages of full CAFR document (F).

+1 Point if individual file(s) providing CAFR data less than $3 \mathrm{MB}$ in size $(\mathrm{G}) . \pm \pm$

+1 Point if official government website provides CAFR data for prior years $(\mathrm{H})$.

+1 Point if official government website provides information on obtaining or access to a printed copy of the government's CAFR (I).

+1 Point if official government website provides contact details (phone and/or email) for individual/department that compiled CAFR (J).

$=$ possible score of 10 points

In this paper, an e-government classified in practicing IFR (Internet Financial Reporting when it provides on the web a comprehensive set of financial statements and/or financial highlights extracted from financial statements (including partial and/or summarized financial statements). The full disclosure is when it provides these four components, namely, balance sheet, budget realization statement, statement of cash flows, and notes to the financial statements.

\section{Result}

Table 3.1 The Quality Disclosure of E-Government of Provincial Governments

\begin{tabular}{|c|c|c|c|c|c|c|c|c|c|c|c|c|c|c|}
\hline \multirow[t]{2}{*}{ No } & \multicolumn{2}{|c|}{$\begin{array}{c}\text { Provincial } \\
\text { Government }\end{array}$} & \multirow[t]{2}{*}{ Status } & \multicolumn{11}{|c|}{ Accessibility Index Value } \\
\hline & $\begin{array}{l}\text { Status per } \\
2015\end{array}$ & June & & $\mathbf{A}$ & B & C & D & $\mathbf{E}$ & $\mathbf{F}$ & $\mathbf{G}$ & $\mathbf{H}$ & I & $\mathbf{J}$ & Total \\
\hline 1 & Bali & & online & 1 & 1 & & & & & 1 & & & 1 & 4 \\
\hline 2 & Banten & & online & 1 & 1 & 1 & 1 & 1 & 1 & & 1 & & 1 & 8 \\
\hline 3 & Bengkulu & & online & 1 & & & & & & & & & & 1 \\
\hline 4 & $\begin{array}{l}\text { Daerah Istimew } \\
\text { Yogyakarta }\end{array}$ & & online & 1 & 1 & & 1 & & & & & 1 & 1 & 5 \\
\hline 5 & $\begin{array}{l}\text { Daerah Khusus } \\
\text { Ibukota Jakarta }\end{array}$ & & online & 1 & 1 & 1 & 1 & & & & 1 & 1 & 1 & 7 \\
\hline
\end{tabular}




\begin{tabular}{|c|c|c|c|c|c|c|c|c|c|c|c|c|c|}
\hline 6 & Gorontalo & online & & 1 & 1 & & 1 & & & & 1 & 1 & 5 \\
\hline 7 & Jambi & online & & 1 & & 1 & & & & & 1 & 1 & 4 \\
\hline 8 & Jawa Barat & online & & 1 & & 1 & & & & & 1 & 1 & 4 \\
\hline 9 & Jawa Tengah & online & 1 & & & & & & & & & & 1 \\
\hline 10 & Jawa Timur & online & 1 & 1 & 1 & & & & 1 & & & 1 & 5 \\
\hline 11 & Kalimantan Barat & online & 1 & 1 & 1 & 1 & 1 & 1 & & 1 & & 1 & 8 \\
\hline 12 & Kalimantan Selatan & online & 1 & 1 & & & & & & & & 1 & 3 \\
\hline 13 & Kalimantan Tengah & online & & 1 & & 1 & & & & 1 & 1 & 1 & 5 \\
\hline 14 & Kalimantan Timur & online & 1 & 1 & & 1 & 1 & & & & & 1 & 5 \\
\hline 15 & $\begin{array}{l}\text { Kepulauan Bangka } \\
\text { Belitung }\end{array}$ & online & & 1 & & 1 & & & & & 1 & 1 & 4 \\
\hline 16 & Kepulauan Riau & online & 1 & & 1 & & & & & & 1 & 1 & 4 \\
\hline 17 & Lampung & online & & & & & & & & & 1 & 1 & 2 \\
\hline 18 & Maluku & online & 1 & & & & & & & & & & 1 \\
\hline 19 & Maluku Utara & offline & & & & & & & & & & & 0 \\
\hline 20 & $\begin{array}{l}\text { Nanggroe Aceh } \\
\text { Darussalam }\end{array}$ & online & 1 & 1 & 1 & 1 & & & 1 & & & 1 & 6 \\
\hline 21 & Nusa Tenggara Barat & online & & 1 & 1 & 1 & & & & & & 1 & 4 \\
\hline 22 & Nusa Tenggara Timur & online & 1 & 1 & & & & & & & & & 2 \\
\hline 23 & Papua & offline & & & & & & & & & & & 0 \\
\hline 24 & Papua Barat & online & 1 & & & & & & & & & & 1 \\
\hline 25 & Riau & online & & & & & 1 & & & & 1 & 1 & 3 \\
\hline 26 & Sulawesi Barat & online & & & & & & & & & 1 & 1 & 2 \\
\hline 27 & Sulawesi Selatan & online & 1 & 1 & & & & & & & & 1 & 3 \\
\hline 28 & Sulawesi Tengah & online & 1 & 1 & & & & & & & & & 2 \\
\hline 29 & Sulawesi Tenggara & online & 1 & & & & & & & & & & 1 \\
\hline 30 & Sulawesi Utara & online & 1 & 1 & & & & & & & & & 2 \\
\hline 31 & Sumatera Barat & online & 1 & 1 & & & & & & & & & 2 \\
\hline 32 & Sumatera Selatan & online & 1 & & & & & & & & & & 1 \\
\hline 33 & Sumatera Utara & online & 1 & 1 & & 1 & & & 1 & & & & 1 \\
\hline 34 & Kalimantan Utara & online & 1 & & & & & & & & & & 1 \\
\hline
\end{tabular}

Results of the survey conducted in the study period related to the official website owned by the 34 provincial governments based on purposive sampling, showed that $94.12 \%$ of e-government in the provincial government is in online status or only 32 e-governments. The remaining $5.88 \%$ or 2 e-governments are in error status (probably in status of under maintenance). The biggest point is in the hand of Banten and Kalimantan Barat with 8 points for the excellent point of 10 .

Table 3.2 The Quality Disclosure of E-Government of Municipal Governments

\begin{tabular}{lllllllllllllll}
\hline No & \multicolumn{1}{c}{$\begin{array}{c}\text { Municipal } \\
\text { Government }\end{array}$} & Status & \multicolumn{1}{c}{ Accessibility Index Value } \\
& Status per & June & & A & B & C & D & E & F & G & H & I & J & Total \\
& $\mathbf{2 0 1 5}$ & & & & & & & & & & & & \\
1 & Denpasar & online & & & & & & & & & & 1 & 1 \\
2 & Serang & online & 1 & 1 & & & 1 & & & & & 1 & 4 \\
3 & Bengkulu & online & 1 & 1 & & & & & & & & 1 & 3
\end{tabular}




\begin{tabular}{|c|c|c|c|c|c|c|c|c|c|c|c|c|}
\hline 4 & Yogyakarta & online & & 1 & & 1 & & & & & 1 & 1 \\
\hline 5 & Jakarta & online & 1 & 1 & 1 & 1 & & & & 1 & 1 & 1 \\
\hline 6 & Gorontalo & offline & & & & & & & & & & \\
\hline 7 & Jambi & online & 1 & 1 & & & & 1 & & & & 1 \\
\hline 8 & Bandung & online & & 1 & & 1 & & & & & 1 & 1 \\
\hline 9 & Semarang & online & 1 & & & & & & & & & \\
\hline 10 & Surabaya & online & & 1 & & 1 & & & & 1 & 1 & 1 \\
\hline 11 & Pontianak & online & & & & & & & & & 1 & 1 \\
\hline 12 & Banjarmasin & online & 1 & 1 & 1 & 1 & 1 & & & & 1 & 1 \\
\hline 13 & Palangkaraya & online & 1 & & & & & & & & & \\
\hline 14 & Samarinda & online & 1 & 1 & 1 & & & 1 & & & & 1 \\
\hline 15 & Pangkal Pinang & offline & & & & & & & & & & \\
\hline 16 & Tanjung Pinang & offline & & & & & & & & & & \\
\hline 17 & Bandar Lampung & online & 1 & 1 & 1 & & & & 1 & & & 1 \\
\hline 18 & Ambon & online & & 1 & & 1 & 1 & & & & 1 & 1 \\
\hline 19 & Sofifi & offline & & & & & & & & & & \\
\hline 20 & Banda Aceh & online & & 1 & 1 & 1 & & & & & 1 & 1 \\
\hline 21 & Mataram & online & 1 & 1 & 1 & 1 & & & 1 & & & 1 \\
\hline 22 & Kupang & online & 1 & 1 & & 1 & & & & & & 1 \\
\hline 23 & Jayapura & online & 1 & & & & & & & & & \\
\hline 24 & Manokwari & online & & & & & & & & & & 1 \\
\hline 25 & Pekanbaru & online & & & & & & & & & & 1 \\
\hline 26 & Mamuju & online & 1 & & & & & & & & & \\
\hline 27 & Makasar & online & & & & & & & & & & 1 \\
\hline 28 & Palu & online & 1 & 1 & & & & & & & & \\
\hline 29 & Kendari & online & & 1 & & 1 & & & & & 1 & 1 \\
\hline 30 & Manado & online & 1 & & & & & & & & & \\
\hline 31 & Padang & offline & & & & & & & & & & \\
\hline 32 & Palembang & online & 1 & 1 & 1 & & & & & & 1 & 1 \\
\hline 33 & Medan & online & 1 & 1 & 1 & 1 & & 1 & & & & 1 \\
\hline 34 & Tarakan & online & 1 & & & & & & & & & \\
\hline
\end{tabular}

Results of the survey conducted in the study period related to the official website owned by the 34 municipal governments based on purposive sampling, showed that only $85.29 \%$ of e-government in the municipal government is in online status or only 29 e-governments. The remaining $14.71 \%$ or 5 e-governments are in error status (probably in status of under maintenance). The biggest point is in the hand of Jakarta and Banjarmasin with 7 points for the excellent point of 10 .

The Mann Whitney Statistical Test is used to compare the quality of financial reporting disclosures based on the accessibility of IFR on government website (e-government) by using Accessibility Index Value between two groups of samples. The index has 10 components (A to J). 
Table $3^{\mathrm{a}}$ (Ranks)

\begin{tabular}{|c|c|c|c|c|}
\hline & GOVERNMENT_GROUP & $\mathrm{N}$ & Mean Rank & Sum of Ranks \\
\hline \multirow[t]{3}{*}{ A } & MUNICIPALITY GROUP & 29 & 29.43 & 853.50 \\
\hline & PROVINCE GROUP & 32 & 32.42 & 1037.50 \\
\hline & Total & 61 & & \\
\hline \multirow[t]{3}{*}{ B } & MUNICIPALITY GROUP & 29 & 30.43 & 882.50 \\
\hline & PROVINCE GROUP & 32 & 31.52 & 1008.50 \\
\hline & Total & 61 & & \\
\hline \multirow[t]{3}{*}{$\mathrm{C}$} & MUNICIPALITY GROUP & 29 & 31.41 & 911.00 \\
\hline & PROVINCE GROUP & 32 & 30.63 & 980.00 \\
\hline & Total & 61 & & \\
\hline \multirow[t]{3}{*}{$\mathrm{D}$} & MUNICIPALITY GROUP & 29 & 31.07 & 901.00 \\
\hline & PROVINCE GROUP & 32 & 30.94 & 990.00 \\
\hline & Total & 61 & & \\
\hline \multirow[t]{3}{*}{$\mathrm{E}$} & MUNICIPALITY GROUP & 29 & 30.16 & 874.50 \\
\hline & PROVINCE GROUP & 32 & 31.77 & 1016.50 \\
\hline & Total & 61 & & \\
\hline \multirow[t]{3}{*}{$\mathrm{F}$} & MUNICIPALITY GROUP & 29 & 31.66 & 918.00 \\
\hline & PROVINCE GROUP & 32 & 30.41 & 973.00 \\
\hline & Total & 61 & & \\
\hline \multirow[t]{3}{*}{$\mathrm{G}$} & MUNICIPALITY GROUP & 29 & 30.10 & 873.00 \\
\hline & PROVINCE GROUP & 32 & 31.81 & 1018.00 \\
\hline & Total & 61 & & \\
\hline \multirow[t]{3}{*}{$\mathrm{H}$} & MUNICIPALITY GROUP & 29 & 30.10 & 873.00 \\
\hline & PROVINCE GROUP & 32 & 31.81 & 1018.00 \\
\hline & Total & 61 & & \\
\hline \multirow[t]{3}{*}{ I } & MUNICIPALITY GROUP & 29 & 31.02 & 899.50 \\
\hline & PROVINCE GROUP & 32 & 30.98 & 991.50 \\
\hline & Total & 61 & & \\
\hline \multirow[t]{3}{*}{$\mathrm{J}$} & MUNICIPALITY GROUP & 29 & 33.14 & 961.00 \\
\hline & PROVINCE GROUP & 32 & 29.06 & 930.00 \\
\hline & Total & 61 & & \\
\hline
\end{tabular}

Table $3^{\mathrm{b}}$ Test Statistics ${ }^{\mathrm{a}}$

\begin{tabular}{|c|c|c|c|c|c|c|c|c|c|c|}
\hline & A & B & $\mathrm{C}$ & $\mathrm{D}$ & $\mathrm{E}$ & $\mathrm{F}$ & $\mathrm{G}$ & $\mathrm{H}$ & I & $\mathbf{J}$ \\
\hline $\begin{array}{l}\text { Mann-Whitn } \\
\text { ey U }\end{array}$ & 418.500 & 447.500 & 452.000 & 462.000 & 439.500 & 445.000 & 438.000 & 438.000 & 463.500 & 402.000 \\
\hline Wilcoxon W & 853.500 & 882.500 & 980.000 & 990.000 & 874.500 & 973.000 & 873.000 & 873.000 & 991.500 & 930.000 \\
\hline $\mathrm{Z}$ & -.808 & -.286 & -.227 & -.034 & -.605 & -.577 & -.728 & -.728 & -.009 & -1.116 \\
\hline $\begin{array}{l}\text { Asymp. Sig. } \\
\text { (2-tailed) }\end{array}$ & .419 & .775 & .820 & .973 & .545 & .564 & .467 & .467 & .993 & .264 \\
\hline
\end{tabular}

a. Grouping Variable: GOVERNMENT_GROUP

\section{Discussion}

Rank of output (Table 3a) shows that the mean value for the provincial government is greater than the value of 
municipal government is (32.42>29.43). From the Mann Whitney Test of statistical test output (Table 3b), the statistic Z value test is -.808 and small sig.2-tailed value is $0.419>0.05$. This means that the test result is not statistically significant. Thus there is no difference in the disclosure of its e-government between the provincial government and the municipal government in the format and quality for the accessibility in the term of if official government website appears on first page of result for Google or Yahoo search using government name and state (A).

Rank of output (Table 3a) shows that the mean values for the provincial government is slightly larger than the value of municipal government is (31.52> 30.43). From the Mann Whitney Test of statistical test output (Table 3b), the statistic $\mathrm{Z}$ value test is -.286 and small sig.2-tailed value is $0.775>0.05$. This means that the test result is not statistically significant. Thus there is no difference in the disclosure of its e-government between the provincial government and the municipal government in the format and quality for the accessibility in the term of if official government website has link to CAFR data on website homepage (B).

Based on rank of output (Table 3a), we can see that the mean value for the municipal government is slightly larger than the value of the provincial government (31.41>30.63). From the Mann Whitney Test of statistical test output (Table 3b), the statistic $\mathrm{Z}$ value test is -.227 and small sig.2-tailed value is $0.820>0.05$. This means that the test result is not statistically significant. Thus there is no difference in the disclosure of its e-government between the provincial government and the municipal government in the format and quality for the accessibility in the term of if official government website has search engine that finds CAFR using terms CAFR and/or financial statements (C).

Based on rank of output (Table 3a), we can see that the mean value for the municipal government slightly larger than the value of the provincial government (31.07>30.94). From the Mann Whitney Test of statistical test output (Table 3b), the statistic $\mathrm{Z}$ value test is -.034 and small sig.2-tailed value is $0.973>0.05$. This means that the test result is not statistically significant. Thus there is no difference in the disclosure of its e-government between the provincial government and the municipal government in the format and quality for the accessibility in the term of if 3 or less web pages (or clicks of mouse) to view CAFR data from government website homepage (D).

Rank of output (Table 3a) shows that the mean value for the provincial government is greater than the value of municipal government is (31.77>30.16). From the Mann Whitney Test of statistical test output (Table 3b), the statistic Z value test is -.605 and small sig.2-tailed value is $0.545>0.05$. This means that the test result is not statistically significant. Thus there is no difference in the disclosure of its e-government between the provincial government and the municipal government in the format and quality for the accessibility in the term of if CAFR provided on official government website as indexed pdf file(s) or HTML format (E).

Based on rank of output (Table 3a), we can see that the mean value for the municipal government slightly larger than the value of the provincial government (31.66>30.41). From the Mann Whitney Test of statistical test output (Table 3b), the statistic $\mathrm{Z}$ value test is -.577 and small sig.2-tailed value is $0.564>0.05$. This means that the test result is not statistically significant. Thus there is no difference in the disclosure of its e-government between the provincial government and the municipal government in the format and quality for the accessibility in the term of if the government provides CAFR data in more than one file; files for different sections/pages of full CAFR document (F).

Rank of output (Table 3a) shows that the mean value for the provincial government is greater than the value of municipal government is (31.81>30.10). From the Mann Whitney Test of statistical test output (Table 3b), the statistic Z value test is -.728 and small sig.2-tailed value is $0.467>0.05$. This means that the test result is not statistically significant. Thus there is no difference in the disclosure of its e-government between the provincial government and the municipal government in the format and quality for the accessibility in the term of if individual file(s) providing CAFR data less than $3 \mathrm{MB}$ in size $(\mathrm{G})$.

Rank of output (Table 3a) shows that the mean value for the provincial government is greater than the value of municipal government is $(31.81>30.10)$. From the Mann Whitney Test of statistical test output (Table $3 \mathrm{~b}$ ), the statistic $\mathrm{Z}$ value test is -.728 and small sig.2-tailed value is $0.467>0.05$. This means that the test result is not statistically significant. Thus there is no difference in the disclosure of its e-government between the provincial government and the municipal government in the format and quality for the accessibility in the term of if official government website provides CAFR data for prior years $(\mathrm{H})$.

Based on rank of output (Table 3a), we can see that the mean value for the municipal government slightly larger than the value of the provincial government (31.02>30.98). From the Mann Whitney Test of statistical test output (Table 3b), the statistic $\mathrm{Z}$ value test is -.009 and small sig.2-tailed value is $0.993>0.05$. This means that the test result is not statistically significant. Thus there is no difference in the disclosure of its e-government between the provincial government and the municipal government in the format and quality for the accessibility in the term of if official government website provides information on obtaining or access to a printed copy of the government's CAFR (I).

Based on rank of output (Table 3a), we can see that the mean value for the municipal government slightly larger than 
the value of the provincial government (33.14>29.06). From the Mann Whitney Test of statistical test output (Table 3b), the statistic $\mathrm{Z}$ value test is -1.116 and small sig.2-tailed value is $0.264>0.05$. This means that the test result is not statistically significant. Thus there is no difference in the disclosure of its e-government between the provincial government and the municipal government in the format and quality for the accessibility in the term of if official government website provides contact details (phone and/or email) for individual/department that compiled CAFR (J).

Based on Table $3 \mathrm{~b}$, all the components are not significant. That is, the results of this study indicate that there is no difference between the quality of financial reporting disclosures or IFR (Internet Financial Reporting) of provincial and municipal governments in Indonesia by using Accessibility Index Value developed by Styles and Tennyson (2000) between two groups of sample.

The phenomena cannot be explained empirically because this study is an exploratory study. But normally, based on the regulatory side, e-government has been introduced in the Presidential Instruction No. 6 of 2001 and Presidential Decree No. 3 of 2003 which is followed by subsequent regulations which is relevant to the use of information technology in government. Based on Verawaty (2012), 87.9\% of provincial governments had the e-government in the status online/active. However, only $37.93 \%$ did the IFR (Internet Financial Reporting). It means that the dissemination of information is closely related to the readiness of the public entity to provide it to be accessible to the public. This paper result also supports Verawaty (2012) that although financially supported by reliable human resources, not all local governments do it.

A number of IFR (Internet Financial Reporting)-related issues and challenges have, however, been noted in the literature. There is a potential that the dividing line between current financial information used by government management made available to public users of financial information could be erased by online, real-time reporting (Oyelere et al, 2003). Besides, if IFR is installed as the only mode for communicating financial information, there is the likelihood that access to such information will be restricted to only those who possess costly computer equipment and skills. Hence, to ensure equity in financial information dissemination, it will be necessary to ensure that the information being reported through websites are already provided previously or simultaneously through other media of financial information disclosure (McCafferty, 1995). This could however be viewed as unnecessary duplication and may result in even greater costs in Indonesia, where financial information are commonly disseminated in both Indonesia and English languages.

Perhaps the greatest challenge faced in the IFR (Internet Financial Reporting) environment is that of ensuring the security and integrity of the financial information published on the websites. Apart from possible errors in the publishing process, materials published on the web are susceptible to all manners of security risks. Financial information could, post-publication, be knowingly or unknowingly altered by parties both external and internal to the organization. There is a real risk that critical decisions could be made by users of financial information based on inaccurate financial information gleaned from the websites. The extent to which these issues are dealt with is likely to determine the long-term usefulness of the internet as a medium of the financial information dissemination.

E-government has allowed government agencies to provide information and deliver services to its internal and external stakeholders through their websites including financial information or initially as IFR (Internet Financial Reporting). The large scale communication offered by government websites presents opportunities for a digital democracy and more transparent accountability to residents and other stakeholders. Considering that accountability is implicit in all the objectives of local and central government financial reporting, government websites can play a role in the democratization of government information on performance by providing convenient and potentially more accessible financial information to stakeholders.

Because the financial statements on the internet are unregulated so many local government consider it not seriously. The Minister of Indonesia for Internal Issues No. 186.52/1797/DJ of 2012 announced that the instruction titled "Building up The Transparency of Budget Management" since May of 2012. It is an obligation for all governments to have a content name "The Transparency of Local Government Budget" in their e-government. More or less it is an IFR (Internet Financial Reporting). Like many other rule or law, it must take time to be applied in their government environment, at least maximally in the following two years. Thus for the future, all government will implement the ministry's instruction so the accountability will support the good governance so there will not be a missing link in national development accountability. The author also recommend that the in every level of the government will develop better knowledge management systems, increase the interactivity of their websites, and enrich the accounting information that they present.

The increasing of personnel for e-government implementation needs a serious treatment. Moreover, it also needs to be conducted jointly by governments, universities, and private parties. The most important and a key to be delivered in the training lie not in the technology but rely on the human ability to manage it. On the managerial side, it needs to be a management model of e-government, for the central government and local government. At the organizational structures in 
departments, ministries and non-departmental government institution, they need to be part of an organization that handles e-government integrated to the duties and functions of the organizational structure in order to avoid confusion in the management and implementation of e-government in local government.

\section{Conclusion}

This study is aimed to compare the quality of financial reporting disclosures (Internet Financial Reporting) at provincial and municipal governments in Indonesia by using Accessibility Index Value developed by Styles and Tennyson (2000). The reasons for selecting the sample group because the provincial government must be highlighted by the public so that it is hypothesized that it will disclose information with better format and quality than the municipal government.

Based on the results of testing with the Mann Whitney Test, all the components are not significant. That is, the results of this study indicate that there is no difference between the quality of financial reporting disclosures or IFR (Internet Financial Reporting) of provincial and municipal governments in Indonesia.

Based on the results of the interview, the lack of problems in optimizing the use of e-government in the field of public sector accounting (financial area), needs the relevant regulations on the use of information technology in government, which is about how the standardization of financial accounting related content areas which is still not mandatory. Delegation of dissemination to local government financial performance reports for the timeliness component is referred to the Supreme Audit Agency's (SAA) authority. This at least can be accommodated through a hyperlink optimization of e-government to SAA website if the government does not want to disseminate to its e-government.

\section{Notes}

The implication of this study is the importance of an institution to regulate and assess the quality of the disclosures made by the local government through its e-government. Of course this will also have implications on the need for regulation on the disclosure of optimizing the utilization of e-government, not only for the province, but also for municipal and municipalities government.

\section{References}

Bagshaw, K. (2000). Financial Reporting on the Internet. Accountants' Digest, Issue 429. The Institute of Chartered Accountants of England and Wales.

Cheng, A., Lawrence, S., \& Coy, D. (2000). Measuring the Quality of Corporate Financial Websites: A New Zealand Study. Paper presented at the 12th Asian-Pacific Conference on International Accounting Issues-Beijing.

Groff, J. E., \& Pitman, M. K. (2004). Municipal Financial Reporting on the World Wide Web: A Survey of Financial Data Displayed on the Official Websites of the 100 Largest US Municipalities. Journal of Government Financial Management, 53(2), 20-30.

Indonesian Government. (2001). Presidential Decree No. 6 of 2001: Telematics (Telecommunications, Media and Information). Indonesia.

Indonesian Government. (2003). Presidential Decree No. 3 of 2003: National Policy and Strategy on the Development of E-Government. Indonesia.

Indonesian Government (2008). Act No. 14/2008: The Disclosure of Public Information. Indonesia.

Indonesian Government (2012). Minister of Indonesia for Internal Issues Instruction No. 186.52/1797/DJ, 2012: Building up The Transparency of Budget Management. Indonesia.

Jaya, A. K., \& Verawaty (2015). The Disclosure of Internet Financial Reporting of Local Government in Indonesia: A Further Review of Government Usage of Information Technology to Provide Public Information. Paper presented at the $1^{\text {st }}$ Social Science, Economics International Conference. Palembang Indonesia, 21-22 February.

Laswad, F., Fisher, R., \& Oyelere, P. (2005). Determinants of Voluntary Internet Financial Reporting by Local Government Authorities. Journal of Accounting and Public Policy, 24, 101-121.

McCafferty, J. (1995). Investor Relations: How Much to Reveal Online. CFO, 12-13.

Mussari, R., \& Steccolini, I. (2006). Using the Internet for Communicating Performance Information. Public Money and Management Journal, 26(3), 193-196.

Oyelere, P., Laswad, F., \& Fisher, R. (2003). Determinant of Internet Financial Reporting by New Zealand Companies. Journal of International Financial Management and Accounting, 14, 1-39.

Styles, A. K., \& Tennyson, M. (2007). The Accessibility of Financial Reporting of US Municipalities on the Internet. Journal of Public Budgeting, Accounting and Financial Management, 19, 56-92.

Verawaty, \& Merina, C. I. (2011). Accessibility of the provincial government IFR (Internet Financial Reporting) in 
Indonesia (Implementation Review of Act No. 14 of 2008 on The Disclosure of Public Information). Paper presented to the scientific meeting of the Kopertis Wilayah II's Research Paper Competition, Palembang, Indonesia, 25-26 September.

Verawaty (2010). The Availability of IFR (Internet Financial Reporting) through E-Government as Public Transparency, Participation, and Accountability Means In South Sumatera. Paper presented to the scientific meeting of the Kopertis Wilayah II's Research Paper Competition, Palembang, Indonesia, 25-26 June.

Verawaty (2012). The Availability of IFR (Internet Financial Reporting) through E-Government as Public Transparency, Participation, and Accountability Means In Indonesia. Proceedings of The 13th Malaysia-Indonesia Conference on Economics, Management and Accounting (MICEMA), Palembang, Indonesia, 562-579.

Verawaty (2014 a). The Analysis Comparison of Internet Financial Reporting of Local Government in Indonesia by Using A Disclosure Index. Proceedings of the 2nd IBEA-International Conference on Business, Economics and Accounting, Hongkong, 164-173.

Verawaty (2014 b). The Accessibility Determinants of Internet Financial Reporting of Local Government: Further Evidence from Indonesia. World Review of Business Research, Vol. 4. No. 2 July 2014, pp. 176-195.

Verawaty (2014 c). The Accessibility of Internet Financial Reporting of Local Government in Indonesia: A Missing Link in National Development Accountability. Paper presented at The Fifth International Conference on Local Government, Palembang, Indonesia, 17-19 September.

Wagenhofer, A. (2003). Economic Consequences of Internet Financial Reporting, Schmalenbach Business Review, 55(4), 262-279.

\section{$(\mathrm{cc}) \mathrm{BY}$}

This work is licensed under a Creative Commons Attribution 3.0 License. 